\title{
PRODUCTION OF MICROBIAL CELLULOSE BY TEA FUNGUS "KOMBUCHA"
}

\author{
Shehata ${ }^{1}$, Sawsan F. and Hussein M. Ali ${ }^{2}$ \\ 1- Department of Agric. Microbiology, Faculty of Agric., Ain Shams Univ., Shoubra El-Kheima, \\ Cairo, Egypt \\ 2- Department of Agric. Biochemistry, Faculty of Agric., Ain Shams Univ., Shoubra El-Kheima, \\ Cairo, Egypt
}

Keywords: Cellulose production, Kombucha, Acetobacter, Static fermentation

\begin{abstract}
In seeking economic production of microbial cellulose, the available and low cost commercial kombucha starter, contains mainly Acetobacter xylinum and Saccharomyces sp., were used under static condition. The best medium composition was black tea extract $\left(1.0 \mathrm{~g} / 100 \mathrm{ml} \mathrm{H} \mathrm{H}_{2} \mathrm{O}\right)$, sucrose $(20 \%)$ and corn steep liquor, CSL $(1 \%)$ at $26-28^{\circ} \mathrm{C}$ for 10 days. The cellulose yield $(1.3 \mathrm{~g} / 100 \mathrm{ml})$ and productive rate $\left(1.3 \times 10^{-3} \mathrm{~g} /\right.$ day $\left./ \mathrm{ml}\right)$ were higher than some reported values. Addition of folic acid or its building block $p$-aminobenzoic acid at additive concentrations $0.20 \%$ led to doubling the yield $(2.37$ and $2.43 \mathrm{~g} / 100 \mathrm{ml}$ culture respectively) and the productive rate $\left(2.37 \times 10^{-3}\right.$ and $2.43 \times 10^{-3} \mathrm{~g} /$ day / $\mathrm{ml}$ respectively). Scanning electron micrograph showed the structure of the produced microbial cellulose fibrils without any microbial flora after treatment with $1 \%$ $\mathrm{NaOH}$.
\end{abstract}

\section{INTRODUCTION}

Cellulose is considered the most abundant biopolymer in plant kingdom. It forms the main structure of the cell wall in most plants and algae; in addition to constituting most of the cotton and > $50 \%$ of the wood structures. Both microbial and plant cellulose consist of $\beta$-1,4-glucose units but the former contains 2000-6000 monomer while the later contains 13000- 14000 glucose unit (Jonas and Farah 1998). Cellulose is used in industry for the production of high strength and biodegradable materials e.g. paper, food additives and artificial blood vessels and skin (Jeong and Lee 2000 and
Klemm et al 2001). Microbial cellulose has the advantage over plant cellulose because of its high purity, light weight, fine network structure and fast biodegradation in addition to its exceptional mechanical strength especially in wet state, enormous water retention value, low roughness of the inner surface and high hydrophilicity which makes the microbial cellulose suitable for medical applications (Klemm et al 2001). However, its disadvantages are its expenses and low yields (Tsuchida and Yoshinaga 1997). Therefore, identifying the microorganisms and the suitable conditions that minimize the cost and maximize the yields of microbial cellulose production is of great concern.

Several organisms have been tested for cellulose production e.g. Acetobacter, Aerobacter, Achromobacter, Agrobacterium, Pseudomonas, Rhizobium and Sarcina where the produced cellulose could be in the form of fibrils, pellicle, ribbons, crystalline or amorphous cellulose (Toyosaki et al 1995; Jonas and Farah 1998 and Astley et al 2001). The chemical composition of the fermentation media and the use of some additives were found to affect cellulose yield. The use of glucose-fructose (Yang et al 1998) or molasses (Bae and Shoda 2005) as a carbon source, and corn steep liquor (CSL) as a nitrogen source (Noro et al 2004) increased the yield. Some vitamins and natural products acted as stimulators for cellulose production e.g. pyridoxine, nicotinic acid, $p$ aminobenzoic acid, biotin, ethanol, caffeine and xanthines (Fontana et al 1991; Jonas and Farah 1998 and Park et al 2003). Kombucha is a symbiosis of bacteria (Acetobacter xylinum, Acetobacter xylinoides and Bacterium gluconium) and some yeast species e.g. Saccharomyces cerevisiae, Schizoscharomyces pombe and Saccharomy- 
codes ludwigii (Sreeramulu et al 2000) that is available commercially at a low cost. It is cultured in sugared black tea where the fermentation media contain small amounts of alcohol, acetic acid, gluconic acid, lactic acid and some antibiotics (Mayser et al 1995). The present work examines the production of microbial cellulose by Kombucha and seeks the suitable low cost condition.

\section{MATERIALS AND METHODS}

Kombucha starter was obtained from Günther W. Frank, Genossenschaftsstr, Birkenfeld, Germany. Corn steep liquor (CSL) containing 3-4\% nitrogen was obtained from Egyptian Starch \& Glucose Company, Helwan, Kotseca. Chemicals were reagent grade and obtained from Sigma or Aldrich Chemical Companies. Micrographs of dried cellulose were recorded by using Scanning Electron Microscope, JEOL T 330A, Central Laboratory, Faculty of Agriculture, Ain Shams University.

The commercial Kombucha starter was cultivated in a tea broth prepared by extracting $0.5 \mathrm{~g}$ black tea by $100 \mathrm{ml}$ boiled water; the fermentation culture contained $10 \%$ sucrose and renewed each 12 days (Sreeramulu et al 2000). The effect of fermentation period (up to 12 days) on cellulose yields was studied; measuring $\mathrm{pH}$ was also performed each 48 hour. The tested sucrose concentrations were $10-45 \%$ while tea extracts were 0.5 $4.0 \mathrm{~g} / 100 \mathrm{ml}$ water; CSL concentrations were 0$9 \%$. The best condition obtained from each experiment was adopted in the following experiments. Additives, $p$-aminobenzoic acid, folic acid, lactic acid, nicotinic acid and glycerol, were tested in various concentrations. Additives were examined in tea broth culture $(1.0 \mathrm{~g} / 100 \mathrm{ml})$ containing Kombucha microorganisms, $20 \%$ sucrose and $1 \%$ CSL for 10 days. Additive concentrations were $0.1,0.2$ and $0.3 \%$, except for glycerol concentrations which were 1.0, 2.0 and $3.0 \%$. All cultures were incubated statically at $26-28^{\circ} \mathrm{C}$. At the end of the fermentation period, cellulose layer was removed and washed twice with distilled water then treated with $\mathrm{NaOH}(1 \%)$ at $90^{\circ} \mathrm{C}$ for 30 minutes (Yang et al 1998). The produced cellulose layer was washed with distilled water and dried at $50^{\circ} \mathrm{C}$ till constant weight was reached.

\section{RESULTS AND DISCUSSION}

Commercial Kombucha starter was used for cellulose production as a cheap and available source of microorganisms cultured in a low cost medium, tea broth under static condition. Kombucha contains mainly two organisms, Acetobacter xylinum and Saccharomyces sp. Acetobacter xylinum was found to produce cellulose under various conditions (Yamanaka 1989; Tsuchida and Yoshinaga 1997 and Krystynowicz et al 2005) while Saccharomyces extracts stimulated its production (Yang et al 1998). The produced cellulose was treated with $1 \% \mathrm{NaOH}$ to get rid of the cell mass then dried at $50^{\circ} \mathrm{C}$ to constant weight; using higher temperature, $80^{\circ} \mathrm{C}$ (Yang et al 1998), yielded darker cellulose. Cellulose yield and $\mathrm{pH}$ were monitored at various intervals up to 12 days. Cellulose yield increased gradually with time; however, the increasing rate of yield decreased about 6 folds after 6 days, where the slopes before and after 6 days were $0.057(\mathrm{R}=0.995)$ and 0.010 $(\mathrm{R}=0.976)$ respectively, which could be attributed to the encountered lowering in the $\mathrm{pH}$ as shown in Fig. (1). Most reports indicated an optimal $\mathrm{pH}$ range for cellulose production 4-7 (Jonas and Farah 1998). The drop in the $\mathrm{pH}$ of the fermented brewer during the incubation period resulted from the conversion of glucose to gluconic acid (Yang et al 1998) and the production of other organic acids.

With respect to the optimum sucrose concentration for cellulose production, it was found to be $20 \%$ in the culture broth medium, where more sucrose concentration led to sharp decline in cellulose production (slope $=-0.017, \mathrm{R}=0.943$ ) as shown in Fig. (2). It was reported that increasing sucrose concentration led to increasing the cell yield (Yang et al 1998), which could be at the expenses of the cellulose production. Results presented in Fig. (3) indicated that the best tea extract for cellulose production ranged from 0.5 to $1.0 \mathrm{~g} /$ $100 \mathrm{ml}$; thereafter, a sharp decrease with a slope $0.268(\mathrm{R}=0.954)$ was recorded. Corn steep liquor (CSL) was found to be effective as a nitrogen source for cellulose production. A maximum cellulose yield $(0.661 \%)$ was obtained by Acetobacter xylinum in a medium containing 6\% CSL (Yang et al 1998). However, in the present investigation, a maximum cellulose yield $(1.30 \%)$ was obtained at $1.0 \%$ CSL. CSL stimulated both cell growth and cellulose production in a A. xylinum culture (Tsuchida and Yoshinaga 1997), which could account for the observed drop in cellulose production with increasing the CSL percentage (Fig. 4). 

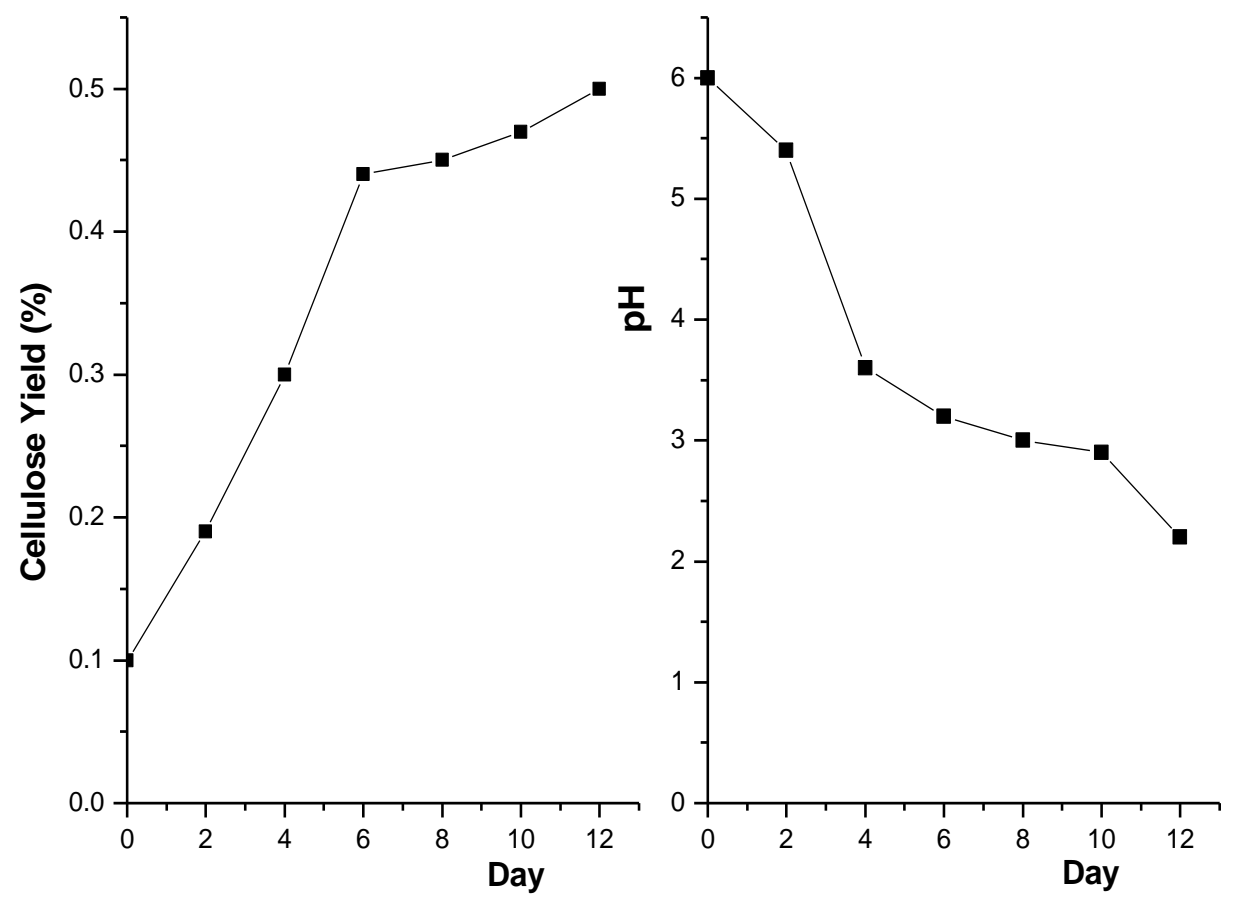

Fig.1. Effect of fermentation period on cellulose yield and $\mathrm{pH}$ using tea extract $(0.5 \mathrm{~g} / 100 \mathrm{ml})$ media containing $10 \%$ sucrose

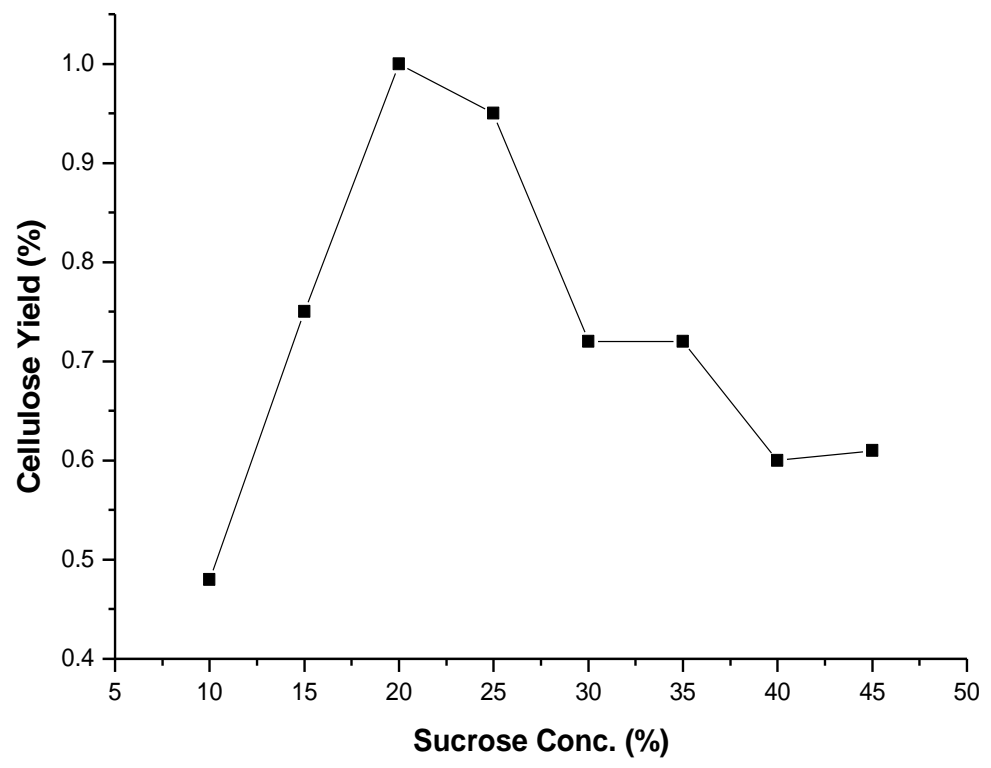

Fig. 2. Effect of sucrose concentration on cellulose production using tea extract $(0.5 \mathrm{~g} / 100 \mathrm{ml})$ media for 10 days 


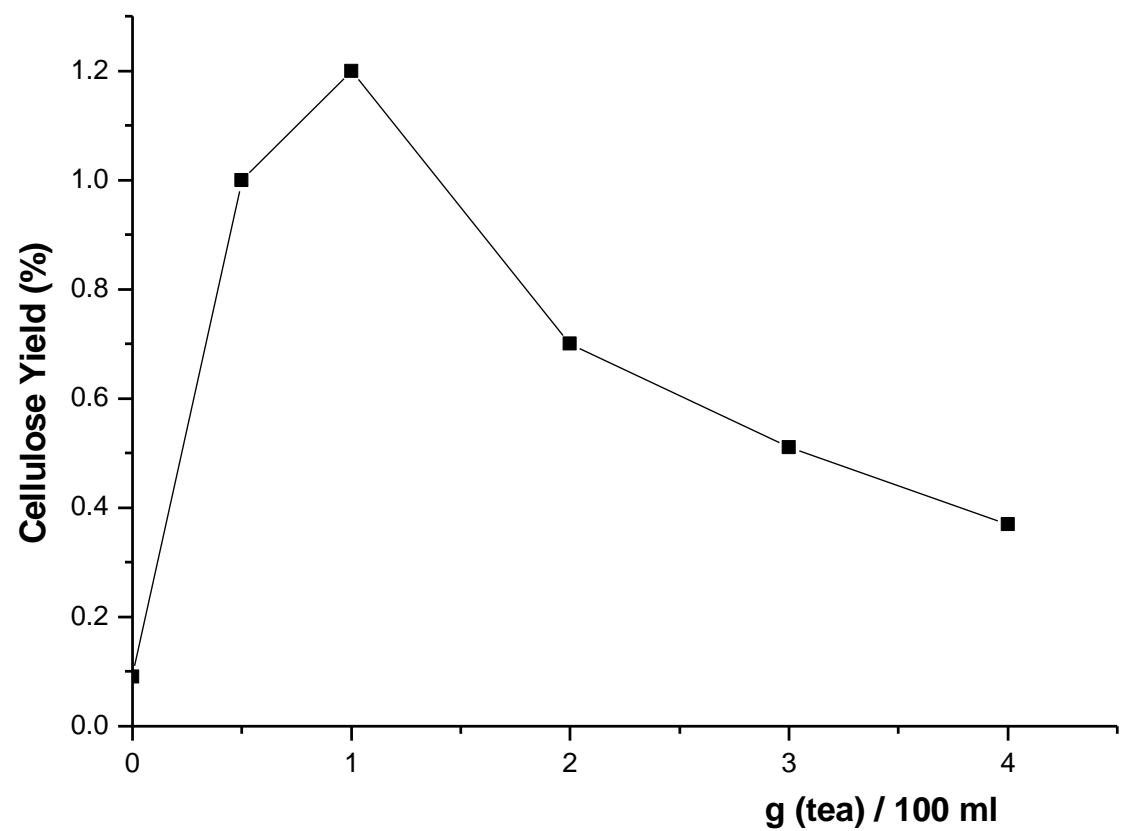

Fig. 3. Effect of tea extract concentration on cellulose production using $20 \%$ sucrose for 10 days

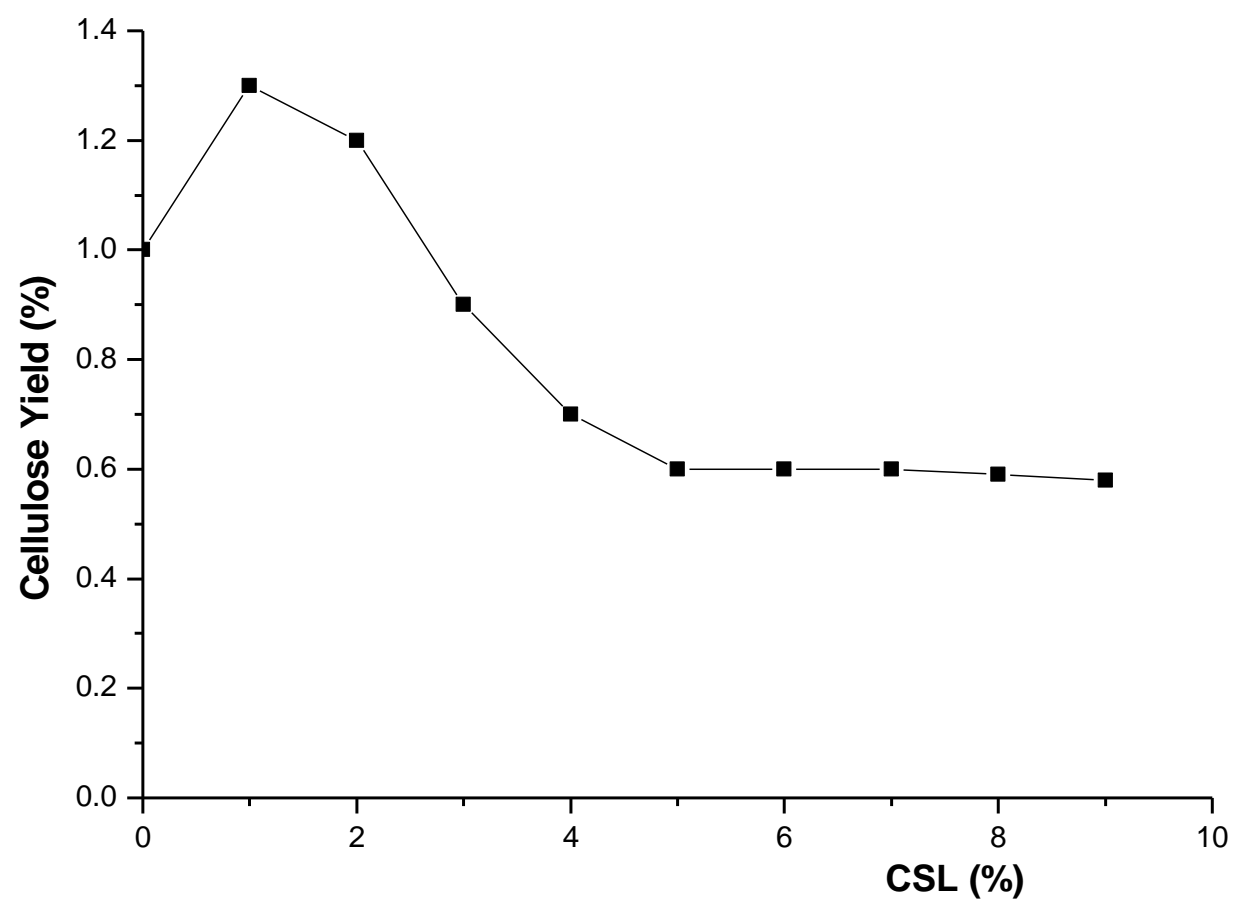

Fig. 4. Effect of CSL on cellulose production using tea extract media $(1.0 \mathrm{~g} / 100 \mathrm{ml})$ containing $20 \%$ sucrose for 10 days 
Effect of various additives i.e. $p$-aminobenzoic acid, folic acid, lactic acid, nicotinic acid and glycerol on cellulose production was examined. The $\mathrm{pH}$ values, at the end of the fermentation period, ranged from 1.8 to 2.2 in all experiments. The control experiment involves cultivating Kombucha organisms in a tea broth (tea extract $1.0 \mathrm{~g} / 100 \mathrm{ml} \mathrm{H}_{2} \mathrm{O}$ ) containing sucrose (20\%) and CSL $(1.0 \%)$ for 10 days. The yield was $1.30 \mathrm{~g} /$ 100

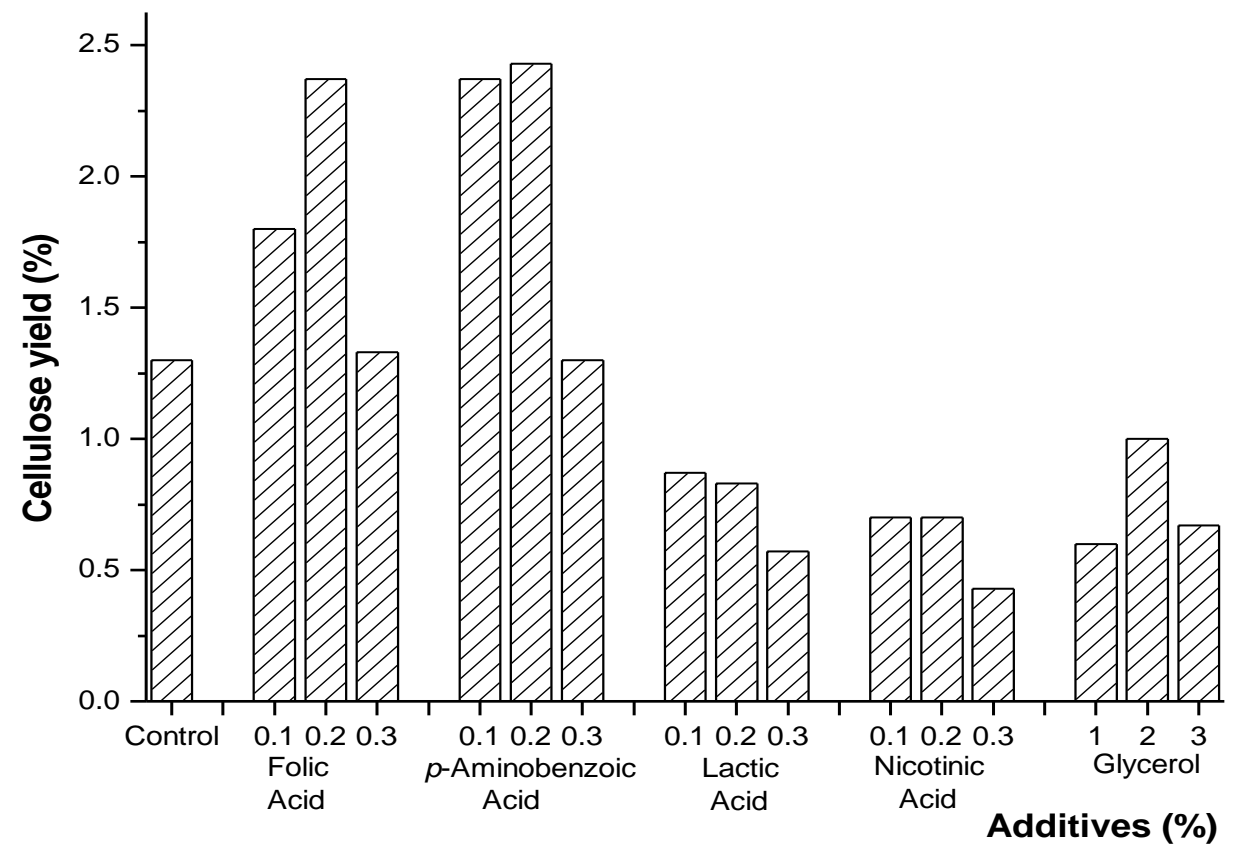

Fig. 5. Effect of some additives on microbial cellulose production

Table 1. Effect of some additives on microbial cellulose production

\begin{tabular}{|lcc|}
\hline \multicolumn{1}{|c}{ Additive } & $\begin{array}{c}\text { Concentration } \\
(\%)\end{array}$ & $\%$ Yield $( \pm$ SD $)$ \\
\hline No additive (control) & - & $1.30( \pm 0.10)$ \\
Folic acid & 0.1 & $1.80( \pm 0.60)$ \\
& 0.2 & $2.37( \pm 0.21)$ \\
p-Aminobenzoic acid & 0.3 & $1.33( \pm 0.42)$ \\
& 0.1 & $2.37( \pm 0.06)$ \\
Lactic acid & 0.2 & $2.43( \pm 0.15)$ \\
& 0.3 & $1.30( \pm 0.50)$ \\
Nicotinic acid & 0.1 & $0.87( \pm 0.06)$ \\
& 0.2 & $0.83( \pm 0.15)$ \\
Glycerol & 0.3 & $0.57( \pm 0.25)$ \\
& 0.1 & $0.70( \pm 0.10)$ \\
& 0.2 & $0.70( \pm 0.30)$ \\
& 0.3 & $0.43( \pm 0.32)$ \\
& 1.0 & $0.60( \pm 0.10)$ \\
& 2.0 & $1.00( \pm 0.10)$ \\
& 3.0 & $0.67( \pm 0.06)$ \\
\hline
\end{tabular}

culture. Results presented in Fig. (5) showed that folic acid and $p$-aminobenzoic acid were the only additives that gave positive effect on cellulose yield. Both additives, at the same concentration (0.20), gave similar yields being 2.37 and $2.43 \%$ respectively (Table 1). $p$-Aminobenzoic acid is a building block of folic acid and incorporates in its biosynthesis. Folic acid is known as a growth factor for some microorganisms (Varley et al 1991). 


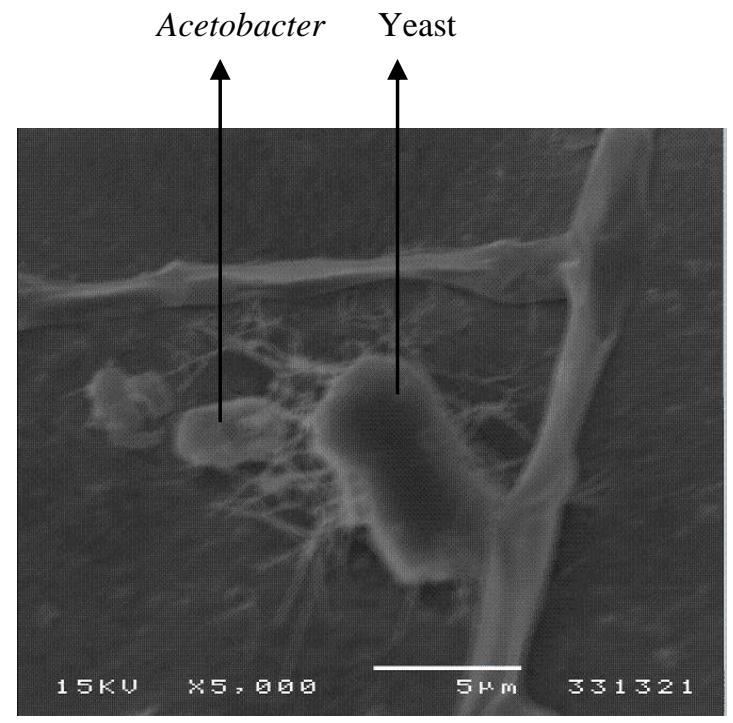

(A)

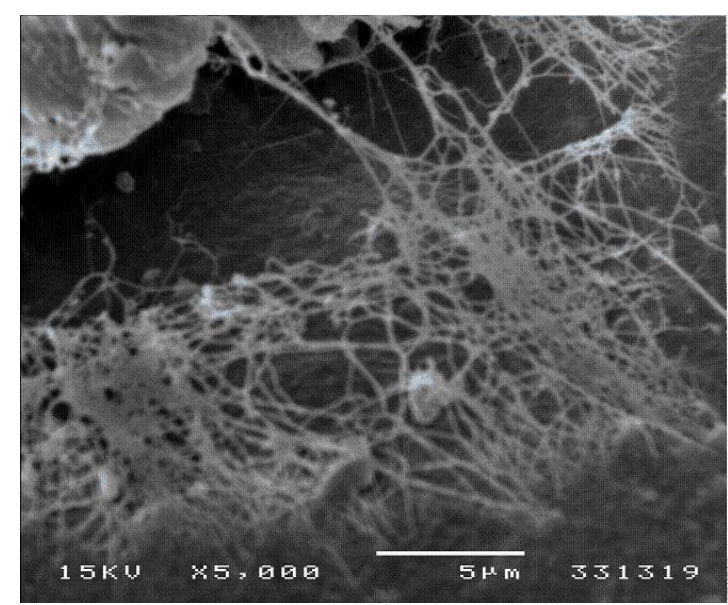

(B)

Fig. 6. Scanning electron micrograph of untreated (A) and treated (B) microbial cellulose fibril with $1 \%$ $\mathrm{NaOH}$

to $2.43 \mathrm{~g} / 100 \mathrm{ml}$ and the productive rate to $2.43 \mathrm{X}$ $10^{-3} \mathrm{~g} /$ day / $\mathrm{ml}$. Therefore, using commercial Kombucha, under our condition, for microbial cellulose production could be more economic and give better yield than those reported in some other investigations.

\section{REFERENCES}

Astley, O.M.; E. Chanliaud; A.M. Donald and M.J.Gidley (2001). Structure of Acetobacter cellulose composites in the hydrated state. Int. J. Biol. Macromol., 29: 193-202.

Bae, S.O. and M. Shoda (2005). Production of bacterial cellulose by Acetobacter xylinum BPR2001 using molasses medium in a jar fermentor. Appl. Microbiol. Biotechnol., 67: 45-51.

Fontana, J.D.; V.C. Franco; S.J. de Souza; I.N. Lyra and A.M. de Souza (1991). Nature of plant stimulators in the production of Acetobacter $x y$ linum ("tea fungus") biofilm used in skin therapy. Appl. Biochem. Biotechnol., 28-29: 341-351.

Jeong, Y.L. and I.S. Lee (2000). A view of utilizing cellulose produced by Acetobacter bacteria. Food Ind. Nutr., 5: 25-29.

Jonas, R. and L. Farah (1998). Production and application of microbial cellulose. Polymer degradation and Stability, 59: 101-106.
Klemm D.; D. Schumann; U. Udhardt and S. Marsch (2001). Bacterial synthesized cellulose artificial blood vessels for microsurgery. Progress in Polymer Science, 26: 1561-1603.

Krystynowicz, A.; M. Koziolkiewicz; A. Wiktorowska-Jezierska; S. Bielecki; E. Klemenska; A. Masny and A. Plucienniczak (2005). Molecular basis of cellulose biosynthesis disappearance in submerged culture of Acetobacter xylinum. Acta Biochem. Pol., 52: 691-698.

Mayser, P.; S. Fromme; C. Leitzmann and K. Gründer (1995). The yeast spectrum of the 'tea fungus Kombucha'. Mycoses, 38: 289-295.

Noro, N.; Y. Sugano and M. Shoda (2004). Utilization of the buffering capacity of corn steep liquor in bacterial cellulose production by Acetobacter xylinum. Appl. Microbiol. Biotechnol., 64: 199-205.

Park, J.K.; J.Y. Jung and Y.H. Park (2003). Cellulose production by Gluconacetobacter hansenii in a medium containing ethanol. Biotechnol. Lett., 25: 2055-2059.

Sreeramulu, G.; Y. Zhu and W. Knol (2000). Kombucha fermentation and its antimicrobial activity. J. Agric. Food Chem., 48: 2589-2594.

Toyosaki, H.; T. Naritomi; A. Seto; T. Tsuchida and F. Yoshinaga (1995). Screening of bacterial cellulose-producing Acetobacter strains suitable 
for agitated culture. Biosci. Biotech. Biochem., 59: 1498-1502.

Tsuchida, T. and F. Yoshinaga (1997). Production of bacterial cellulose by agitation culture systems. Pure \& Appl. Chem., 69: 2453-2458.

Varley, H.V.; A.H. Gowenlock and M. Bell (1991). Practical Clinical Biochemistry. 5th Ed. Vol. 2 pp. 235-237. GBS Publishers \& Distributors, Delhi, India.
Yamanaka, S. (1989). Cellulosics UtilizationResearch and Rewards in Cellulosics. pp. 175181. Inagaki H. and G.O. Philips (eds), Elsevier Science Publishers, New York.

Yang, Y.K.; S.H. Park; J.W. Hwang; Y.R. Pyun and Y.S. Kim (1998). Cellulose production by Acetobacter xylinum BRC5 under agitated condition. J. Fermentation and Bioengineering, 85: 312-317.

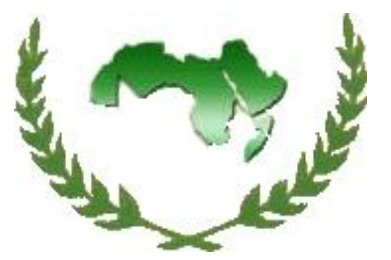

$$
\begin{aligned}
& \text { مجلة اتحاد الجامعات العربية }
\end{aligned}
$$

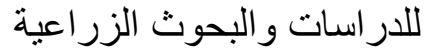

$$
\begin{aligned}
& \text { جامعة عين شمس ، القاهرة }
\end{aligned}
$$

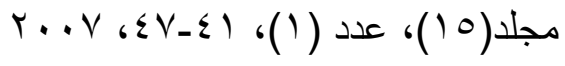

أنتاج السليولوز الميكروبى بفطر الثاى "الكمبوشـا"

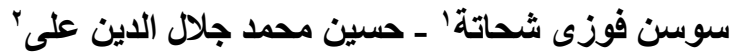

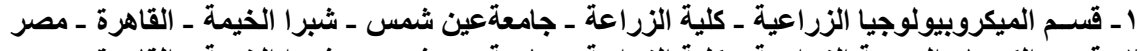

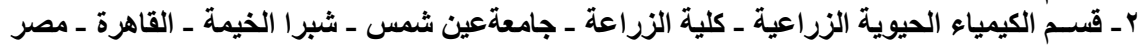

$$
\begin{aligned}
& \text { لأنتاج سـليولوز ميكروبسى إقتصـادى تـم إسـتخدام }
\end{aligned}
$$

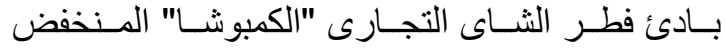

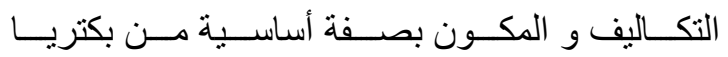

$$
\begin{aligned}
& \text { الأسيتوباكتر و فطر الخميرة، و ذلك بتقنيـة المزرعـة الفية }
\end{aligned}
$$

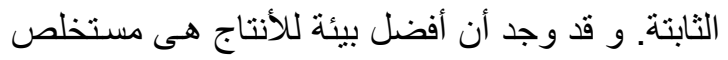

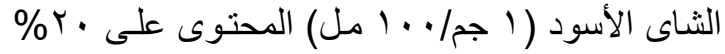

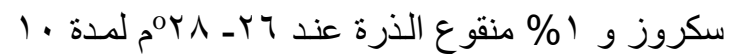

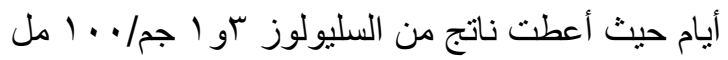

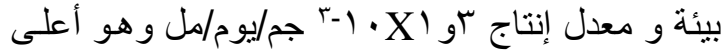

تحكيـم: أ.د الشحات محمد رمضان 